\title{
PEMBELAJARAN SMART GO-CLASFORME UPAYA MENINGKATKAN HASIL BELAJAR MATERI MATRIKS DI MASA PANDEMI KELAS XI AKL 2 SMKN 1 JUWIRING
}

\author{
HENI BUDIANTI \\ SMKN 1 Juwiring \\ e-mail: budiantihenik@gmail.co.id
}

\begin{abstract}
ABSTRAK
Pembelajaran daring kini menjadi pembelajaran wajib di setiap lembaga pendidikan. guru harus terus mempelajari strategi untuk meningkatkan pemahaman dan kompetensi terkait pembelajaran online agar pembelajaran online dapat berjalan dengan relatif baik dan menghasilkan prestasi belajar siswa yang baik. Penggunaan teknologi secara tepat sasaran yang mampu menjawab berbagai tantangan dan kesulitan pembelajaran yang ada dan kecakapan digital yang cerdas dan bijak dalam penggunaan teknologi. Tujuan dari penelitian ini adalah bagaimana implementasi pembelajaran SMART Go-ClassForMe dapat meningkatkan hasil belajar siswa pada materi matriks di masa pandemi.Subjek penelitian adalah siswa kelas XI Akuntansi Keuangan 2 yang berjumlah 35 siswa melalui tahap perancangan, tahap pelaksanaan dan tahap evaluasi. Hasil dari penelitian menunjukan bahwa pembelajaran SMART GOClassForMe efektif diterapkan di masa pandemi, dengan ada peningkatan nilai hasil prestasi belajar untuk nilai rata-rata pretest 49,6 \% dan nilai rata-rata posttest menjadi $79,03 \%$ dan meningkatnya keikutsertaan kehadiran dalam pembelajaran daring, sehingga pembelajaran dengan metode SMART GO-ClassForMe dengan alur yang sistematis dapat meningkatkan rasa percaya diri siswa, antusiasme siswa yang ditandai dengan tingginya kehadiran siswa dan meningkatnya hasil belajar siswa..
\end{abstract}

Kata kunci: Pembelajaran daring, Pembelajaran SMART GO-ClassForMe

\begin{abstract}
Online learning is now a mandatory learning in every educational institution. teachers must continue to study strategies to improve understanding and competence related to online learning so that online learning can run relatively well and produce good student learning achievements. The right use of technology that is able to answer the various challenges and difficulties of existing learning and digital skills that are smart and wise in the use of technology. The purpose of this study is how the implementation of SMART Go-ClassForMe learning can improve student learning outcomes on matrix material during the pandemic. The subjects of the study were students of class XI Financial Accounting 2, totaling 35 students through the design stage, implementation stage and evaluation stage. The results of the study show that the SMART GOClassForMe learning is effectively applied during the pandemic, with an increase in the value of learning achievement results for the average pretest value of $49.6 \%$ and the posttest average value of $79.03 \%$ and increased participation in learning. online, so that learning with the SMART GO-ClassForMe method with a systematic flow can increase students' self-confidence, student enthusiasm which is marked by high student attendance and increased student learning outcomes.
\end{abstract}

Keywords: Online learning, SMART GO-ClassForMe Learning

\section{PENDAHULUAN}

Pembelajaran matematika yang berkualitas ditunjukan dengan kesiapan perencanaan pembelajaran, proses pembelajaran yang apik dan evaluasi yang terukur baik pembelajaran secara luring maupun daring. Guru perlu menfasilitasi pembelajaran daring yang salah satunya difokuskan pada kemampuan literasi dan numerasi siswa (Kemdikbud:2020). Guru diharapkan mampu memfasilitasi pembelajaran jarak jauh melalui media video conference dan Learning managemen system (Kemdikbud:2020). Pembelajaran daring merupakan pembelajaran yang 
menggunakan jaringan internet dan perangkat pendukung dengan aksesibilitas, konektivitas, fleksibilitas, dan kemampuan untuk memunculkan berbagai jenis interaksi pembelajaran antara pendidik dengan peserta didik (Sadikin:2020). Keberhasilan proses belajar dan mengajar daring akan sangat dipengaruhi oleh kemampuan guru menggunakan teknologi dalam menyampaikan materi pembelajaran. (Assidiqi:2020). Hasil penelitian handayani (2020) menemukan bahwa pembelajaran daring kurang efektif karena faktor kejenuhan anak, penjelasan guru yang kurang jelas, banyaknya tugas dari guru dan kurangnya pengetahuan orang tua dalam mendampingi putra-putrinya di rumah. Jadi di masa pandemi seorang guru matematika harus menguasai teknologi, media dan learning managemen system agar pembelajaran matematika dapat berlangsung secara maksimal walaupun tanpa tatap muka secara langsung. Perangkat pembelajaran, proses pembelajaran dan evaluasi yang diterapkan ke siswa harus berkualitas dan tidak membuat jenuh siswa sehingga hasil belajar siswa maksimal.

Keberhasilan seorang guru dalam kegiatan belajar mengajar sangat tergantung pada kecakapannya dalam menerapkan metode pembelajaran, jadi tidak tergantung pada metodenya karena tidak ada metode yang paling baik dan buruk untuk diterapkan dalam pembelajaran sehingga dapat meningkatkan ataupun menurunkan prestasi belajar mengajar siswanya.(Rahman:2011). Dimasa pandemi covid-19 ini guru perlu mengubah model pembelajaran yang teacher centered menjadi student centered untuk melatih kemampuan pemecahan masalah mandiri siswa, yang dimasa pandemi ini memiliki kesulitan lebih daripada tatap muka. Tantangan lain yang guru SMKN 1 Juwiring temui adalah keterbatasan perangkat belajar anak, paket data, dan kedisiplinan siswa dalam keaktifan pembelajaran atau keikutsertaan aktif dalam pengumpulan tugas, latihan pembahasan soal atau dalam ulangan harian. Beberapa kendala tersebut membuat prestasi belajar siswa SMKN 1 Juwiring utamanya kemampuan pemecahan masalah matematika menjadi rendah di semester sebelumnya. Padahal kemampuan pemecahan masalah matematika sangat penting bagi siswa untuk mendapatkan hasil belajar pelajaran matematika yang baik. Kendala guru untuk melatih kemampuan pemecahan masalah siswa ini mendorong penulis untuk mengembangkan "pembelajaran SMART Go-ClassForMe" yang diharapkan dapat memaksimalkan kemampuan pemecahan masalah materi matriks. Pembelajaran yang dilakukan dengan pembelajaran yang mengintegrasikan beberapa media yaitu Google classroom, Google form, Google meet, WhatsApp, youtube. Integrasi berbagai media pembelajaran tersebut diharapkan siswa senantiasa merasakan hal-hal baru, yang akan memunculkan motivasi belajar siswa, sehingga siswa menjadi lebih aktif dan merasa senang dan semangat belajarsehingga dapat meningkatkan hasil belajar siswa khususnya materi matriks.

Rancangan pembelajaran SMART ( Sehat Menyenangkan Antusias Real Terkontrol) dengan melalui GO-ClassForMe mempunyai arti gabungan dari beberapa maksud, yaitu : (1). Google Classroom adalah suatu serambi aplikasi pembelajaran campuran secara online yang dapat digunakan secara gratis. Google Classroom ini diperuntukkan untuk semua ruang lingkup pendidikan yang membantu siswa untuk menemukan atau mengatasi kesulitan pembelajaran, membagikan pelajaran dan membuat tugas tanpa harus hadir ke kelas. (2). Google Form, dalam dunia pendidikan bisa berfungsi sebagai : (a) memberikan tugas latihan/ulangan online (b) Mengumpulkan berbagai data siswa/guru (c) membagikan kuesioner kepada orang-orang secara online. (3). Google Meet, media aplikasi pembelajaran yang paling direkomendasikan tentunya dapat mendukung interaksi antara guru dan siswa secara efektif. Dimana proses pembelajaran dapat dilakukan melalui video conference, yang tidak hanya berinteraksi secara audio tetapi juga dapat bertatap muka meskipun tidak secara langsung, istilah sekarang "bertatap layar". (4). Group WhatsApps, WhatsApp adalah aplikasi gratis yang menyediakan layanan bertukar pesan dan panggilan yang sederhana, aman, dan reliabel serta tersedia pada berbagai telepon di seluruh dunia. Dengan menggunakan WhatsApp, kita dapat melakukan obrolan daring, berbagi file, bertukar foto, dan lain-lain. Dan aplikasi ini adalah yang paling disukai oleh siswa karena aplikasi gratis sehingga siswa pasti siapapun mampu menggunakanya dengan mudah. 


\section{METODE PENELITIAN}

Penulis melaksanakan pembelajaran Daring menggunakan metode SMART GOClassForMe sebagai bentuk inovtif guru dalam upaya lebih mengefektifkan proses pembelajaran daring yang sangat sesuai dengan kondisi pandemic Covid-19, dan model pembelajaran daring (online) dimana peserta didik melaksanakan belajar dari rumah. Best Practice ini menggambarkan tentang keadaan atau kondisi pembelajaran dimana baik peserta didik atau guru dapat lebih efektif dalam pembelajaran daring, diskripsi pembelajaran SMART GO-ClassForMe dapat dilihat dalam bentuk dokumentasi berupa absensi, jadwal, foto/screenhoot kegiatan materi pelajaran, media pembelajaran GO-ClassForMe.

Best Practice dilaksanakan pada semester ganjil tahun pelajaran 2021/2022 mulai bulan Juli sampai dengan September 2020. Tempat pelaksanaan Best Practice adalah SMKN 1 Juwiring. Metode atau strategi yang digunakan adalah metode pembelajaran daring dengan menggunakan media pembelajaran GO-ClassForMe berupa aplikasi: Google Classroom, Google Form, Google Meet, Group whatsApp. Materi yang digunakan untuk pembelajaran daring adalah materi mata pelajaran Matematika tentang Matriks pada kelas XI AKL 2 semester Ganjil. Metode dalam GO-ClassForMe yang digunakan dalam pembelajaran daring meliputi tahap perencanaan, tahap pelaksanaan, dan tahap evaluasi.

\section{Tahap Perencanaan GO-ClassForMe}

Tahap pembelajaran daring GO-ClassForMe ini rancangan yang harus dipersiapkan sebelumnya adalah sebagai berikut :

1. Membuat group WhatsApp Mata pelajaran

2. Membagikan link absensi harian pembelajaran SMART GO-ClassForMe melalui Ms.Form

3. Mempersiapkan Ruang kelas pembelajaran daring GO-ClassForMe bagi siswa tentunya di Google Classroom

4. Mempersiapkan materi yang akan di bagikan saat pembelajaran GO-ClassForMe di google classroom baik dalam bentuk Video pembelajaran, File Pdf, Power point, Foto, dan lainnya.

5. Mempersiapkan beberapa soal pretes dan tugas, ulangan, di Google Form

6. Mempersiapkan perencanaan atau schedule akan dilakukan pembelajaran $G O$ ClassForMe di Google meet.

\section{Tahap Pelaksanaan GO-ClassForMe}

Gambaran pelaksanaan pembelajaran daring SMART GO-ClassForMe materi matriks dapat disajikan sebagai berikut:

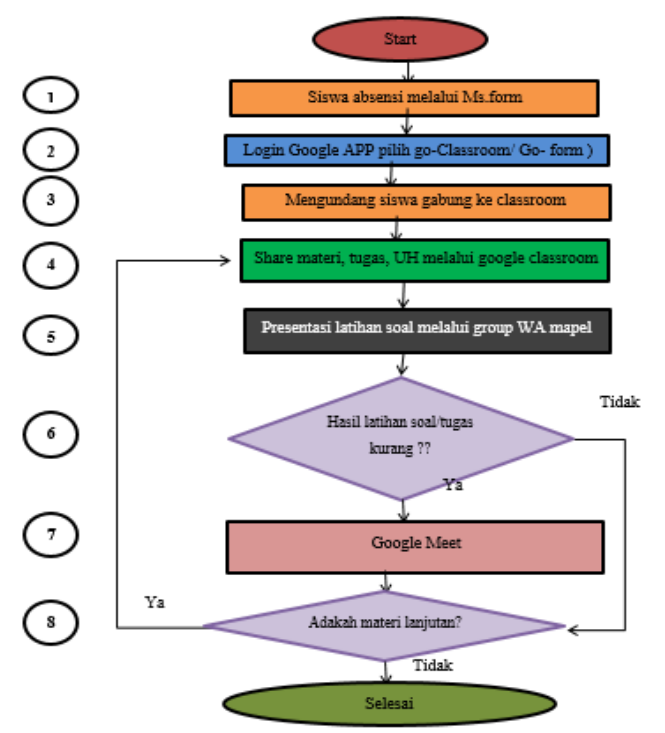

Gambar 1. Gambaran pelaksanaan pembelajaran GO-ClassForMe 
Keterangan langkah-langkah pelaksanaan GO-ClassForMe

Langkah ke-1 : Peserta didik absensi di Google form

Questions Responses Settings

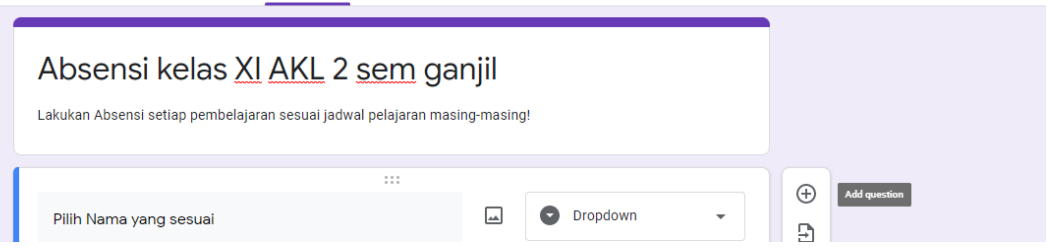

Gambar 2. Tampilan Form Absensi pembelajaran daring sem ganjil

Langkah ke-2 : Login Google APP Pilih google classroom
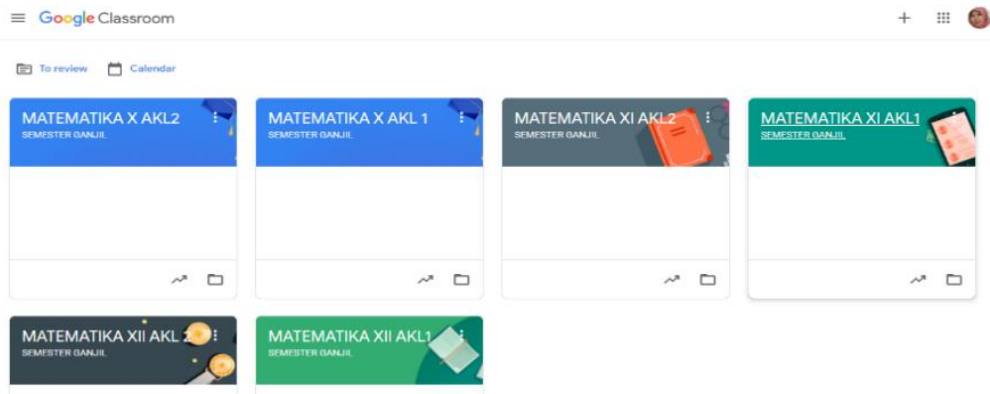

Gambar 3. Kelas yang akan diajarkan semester ganjil pada google classroom

Langkah ke-3 : Mengundang siswa gabung ke classroom

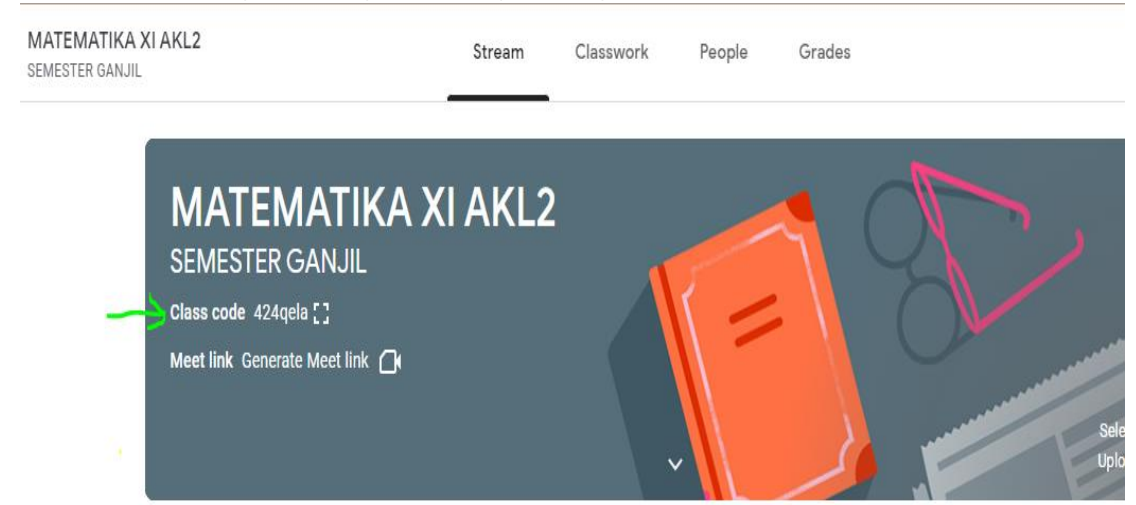

Gambar 4. Tampilan Class code yang akan dishare ke peserta didik untuk bergabung

Langkah ke-4 : Share materi, tugas, ulangan melalui google classroom

Didalam google classroom tempat semua kegiatan pembelajaran diberikan baik pengiriman materi yang dalam bentuk video pembelajaran, materi dalam bentuk file Pdf, materi dalam bentuk power point, materi dalam bentuk foto dan lain lain. Untuk soal tugas atau soal ulangan yang dibuat di google form juga di kirimkan ke google classroom. Sehingga segala hal kegiatan dapat teradministrasikan dengan rapi di google classroom 
目 Tugas 3 : operasi matriks

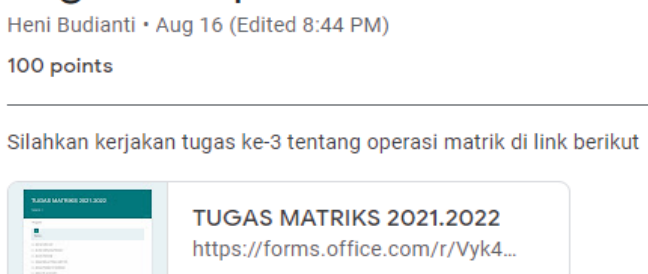

Gambar 5. Contoh share tugas ke google classroom dalam bentuk google form

Langkah ke-5 : Presentasi latihan soal melalui Group WA mapel

Setelah mengirimkan materi ke google classroom, siswa melanjutkan mengerjakan latihan soal yang saat di kelas biasanya siswa ditunjuk untuk mengerjakan di papan tulis, di pembelajaran SMART GO-ClassForMe siswa ditunjuk untuk menshare jawaban di group WA mapel kemudian nanti dikoreksi dan di bahas sehingga yang lain juga bisa meihat hasil jawaban penyelesaian yang benar di group WA mapel tersebut.
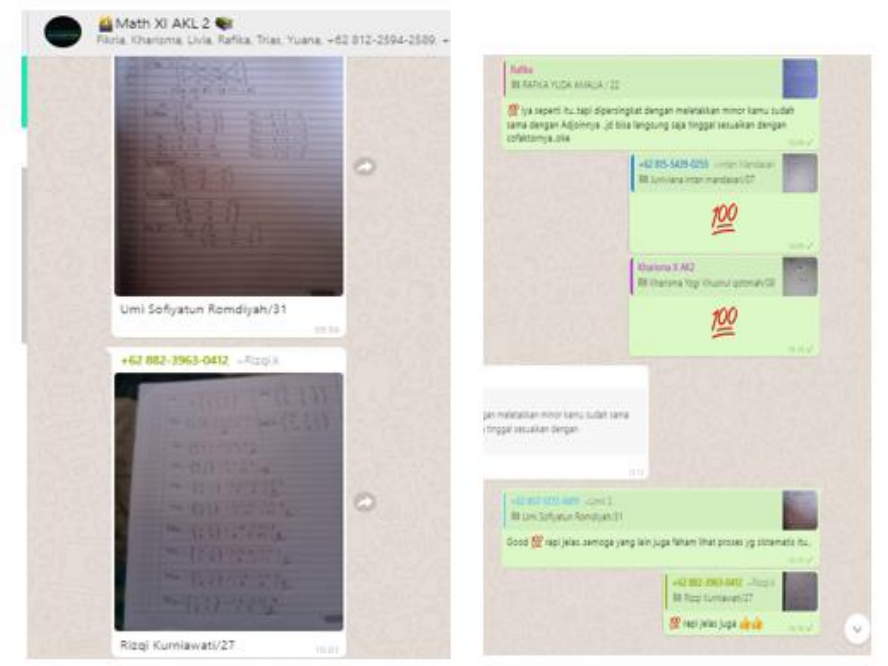

Gambar 6. Tampilan Group WA jawaban siswa yg ditunjuk di koreksi, diberi penilaian, dan komentar dari guru

Langkah ke-6 : Hasil Latihan soal/tugas kurang??

Jika terdapat 30 persen peserta didik tidak menguasai materi saat di latihan soal atau tugas maka dilanjutkan dengan Google Meet, tapi jika dari hasil latihan soal/tugas sudah relatif bagus makan dilanjutkan ke materi selanjutnya.

Langkah ke-7 : Google Meet

Google meet dilakukan secara terencana atau terscedule apabila ada hal-hal tertentu yag dianggap perlu untuk pembelajaran secara langsung. Biasanya untuk materi yang perlu penjelasan lebih detail atau saat siswa banyak yang kurang faham akan materi tertentu 


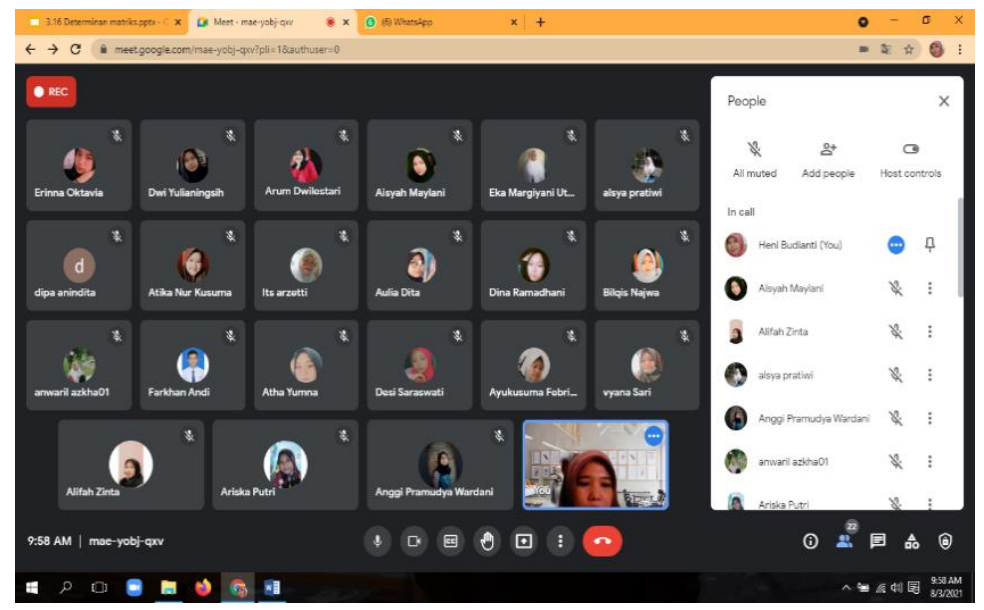

Gambar 7. Tampilan saat berlangsung pembelajaran di google meet

Langkah ke-8 : Adakah Materi lanjutan?

Apabila pada langkah ini ada materi lanjutan yang masih belum dijelaskan dalam satu kompetensi dasar, maka langkahnya akan sama dan langkah akan kembali dimulai dari langkah yang ke 3 yaitu Share materi, tugas, ulangan melalui google classroom, dan seterusnya.

Langkah ke-9 : Selesai

Jika proses pembelajaran SMART GO-ClassForMe selesai, biasanya guru akan melalukan evalusi materi matriks.

\section{Tahap Evaluasi GO-ClassForMe}

Tahap evaluasi dilakukan dengan mengolah hasil kemampuan peserta didik dalam pemecahan masalah materi matriks sebelum dan sesudah pelaksanaan pembelajaran daring SMART GO-ClassForMe. Pengolahan dilakukan dengan membandingkan rata-rata hasil pretes materi matriks dengan hasil post tes materi matriks pada kelas XI AKL 2.

\section{HASIL DAN PEMBAHASAN}

Belajar adalah proses kegiatan yang dilakukan dengan sengaja untuk mengubah sikap dan perilaku (Setiawati, 2018), Pembelajaran yang mengadopsi hasil pemikiran dan rancangan suatu ide yang diwujudkan dalam produk tertentu dan menyediakan kenyamanan dalam belajar menjadi pemahaman tentang teknologi pembelajaran (Khayati \& Sarjana, 2015). Belajar adalah proses yang dibangun untuk mengembangkan siswa berpikir kreatif dan dipegang sebagai upaya untuk meningkatkan keterampilan berpikir siswa, kemampuan untuk membangun pengetahuan baru, dan kemampuan untuk memahami materi pelajaran dengan baik, dan diselenggarakan dengan tujuan membantu siswa untuk belajar dengan sebaik mungkin dengan perkembangan ilmu pengetahuan dan teknologi, penerapan pembelajaran juga berubah melalui penggunaan informasi dan teknologi komunikasi dalam pembelajaran. Guru dituntut untuk mampu siapkan generasi dengan menempatkan tiga hal utama dalam pembelajaran diantaranya keterampilan belajar dan inovasi, keterampilan dalam memanfaatkan informasi, media, dan teknologi; dan keterampilan hidup dan karir. Guru memiliki tanggung jawab yang besar untuk mengantarkan siswa ke pendidikan yang diinginkan (Sarjana \& Khayati, 2016).

Pembelajaran sebagai proses yang dibangun untuk siswa berpikir kreatif dan kritis disini peneliti menggunakan pembelajaran daring dengan SMART GO-ClassForMe. Ada beberapa hal yang harus selalu diamati saat berlangsungnya pembelajaran , diantaranya;

1. Proses pembelajaran akan berhasil jika siswa memiliki motivasi didalam dirinya. Oleh karena itu, guru juga berperan penting dalam menumbuhkan motivasi dan semangat dalam diri siswa untuk semangat belajar secara daring, misalnya di awal pembelajaran guru 
menyapa, memberi semangat dan juga mengingatkan untuk selalu melakukan absensi sebagai bentuk semangat keikutsertaan dalam pembelajaran daring sehingga saat ada beberapa siswa yang tidak absen kita sebagai guru mengkontrol dan mengingatkan di group WA mapel, sehingga tidak akan ketinggalan absen dan tidak ketinggalan pembelajaran SMART GO-ClassForMe .

\begin{tabular}{|c|c|c|c|c|}
\hline Waktu mulai & Waktu selesai & $\nabla$ Nama & $\nabla$ Nama2 & Tanggal Absensi NoAbsen \\
\hline 7/14/217:50:28 & 7/14/21 7:50:48 anonymous & & JUNIVIANA INTAN MA & 7/14/2021 07 \\
\hline 7/14/217:53:25 & 7/14/21 7:53:51 anonymous & & MUTIARA YULIANA & 7/14/2021'11 \\
\hline 7/14/217:58:22 & $7 / 14 / 217: 58: 33$ anonymous & & VENITA SELLY JAYANTI & $7 / 14 / 20211^{\prime} 32$ \\
\hline 7/14/21 8:00:09 & 7/14/21 8:02:25 anonymous & & NIA RAMADHANI & $7 / 14 / 2021^{\prime} 17$ \\
\hline 7/14/21 8:07:00 & $7 / 14 / 218: 07: 15$ anonymous & & SABRINA RIZQA HASAI & $7 / 14 / 202128$ \\
\hline $7 / 14 / 218: 10: 14$ & 7/14/21 8:10:39 anonymous & & RENI NOVITASARI & $7 / 14 / 2021^{\prime} 23$ \\
\hline 7/14/21 8:12:56 & 7/14/21 8:13:16 anonymous & & YAUANA PUTRY NURH, & $7 / 14 / 202134$ \\
\hline $7 / 14 / 218: 13: 13$ & $7 / 14 / 21$ 8:13:31 anonymous & & ZAHRA FIRLANI AZIZAF & $7 / 14 / 2021^{\prime} 35$ \\
\hline $7 / 14 / 218: 13: 56$ & $7 / 14 / 218: 14: 04$ anonymous & & INSANIYAH FIRDAUSI & 7/14/2021'04 \\
\hline $7 / 14 / 218: 14: 21$ & 7/14/21 8:14:56 anonymous & & TRIAS PUTRI KINANTI & $7 / 14 / 2021^{\prime} 29$ \\
\hline $7 / 14 / 218: 25: 48$ & 7/14/21 8:26:05 anonymous & & NABELLA NUR ASRI & $7 / 14 / 202112$ \\
\hline $7 / 14 / 218: 26: 09$ & 7/14/21 8:26:51 anonymous & & RIZKA DWI SAPUTRI & $7 / 14 / 2021^{\prime} 26$ \\
\hline $7 / 14 / 218: 26: 36$ & $7 / 14 / 218: 26: 52$ anonymous & & NURUL FITRIA & $7 / 14 / 202120$ \\
\hline $7 / 14 / 218: 29: 16$ & 7/14/21 8:29:33 anonymous & & NADIA A'YUNI SYAHID, & $7 / 14 / 2021^{\prime} 13$ \\
\hline 7/14/21 8:43:26 & 7/14/21 8:43:36 anonymous & & UMI SOFIYATUN ROML & $7 / 14 / 2021 ' 31$ \\
\hline 7/14/21 8:43:35 & 7/14/21 8:43:43 anonymous & & RAFIKA YUDA AMALIA & $7 / 14 / 2021^{\prime 22}$ \\
\hline $7 / 14 / 218: 43: 42$ & 7/14/21 8:43:52 anonymous & & TRININGSIH STIYAWAT & $7 / 14 / 202130$ \\
\hline $7 / 14 / 218: 45: 05$ & 7/14/21 8:45:23 anonymous & & RIYANTI RAHMADHAN & $7 / 14 / 202125$ \\
\hline $7 / 14 / 218: 45: 34$ & 7/14/21 8:45:53 anonymous & & NIA SARI CITRA RAMAI & $7 / 14 / 202121$ \\
\hline $7 / 14 / 218: 46: 10$ & $7 / 14 / 218: 46: 21$ anonymous & & RIZQI KURNIAWATI & $7 / 14 / 202127$ \\
\hline
\end{tabular}

Gambar 8. Tampilan absensi pembelajaran SMART GO-ClassForMe harian.

2. Berkaitan dengan kemampuan guru dalam menguasai materi pelajaran, mengelola pembelajaran. Dan guru sebagai fasilitator dimana guru memberikan pelayanan kepada siswa untuk dapat memudahkan siswa menerima materi pelajaran. Sehingga pembelajaran menjadi efektif dan efisien.Disini guru menjadi sumber pemberi materi, tugas, ulangan dan mengelola pembelajaran di dalam google classroom seperti berikut :
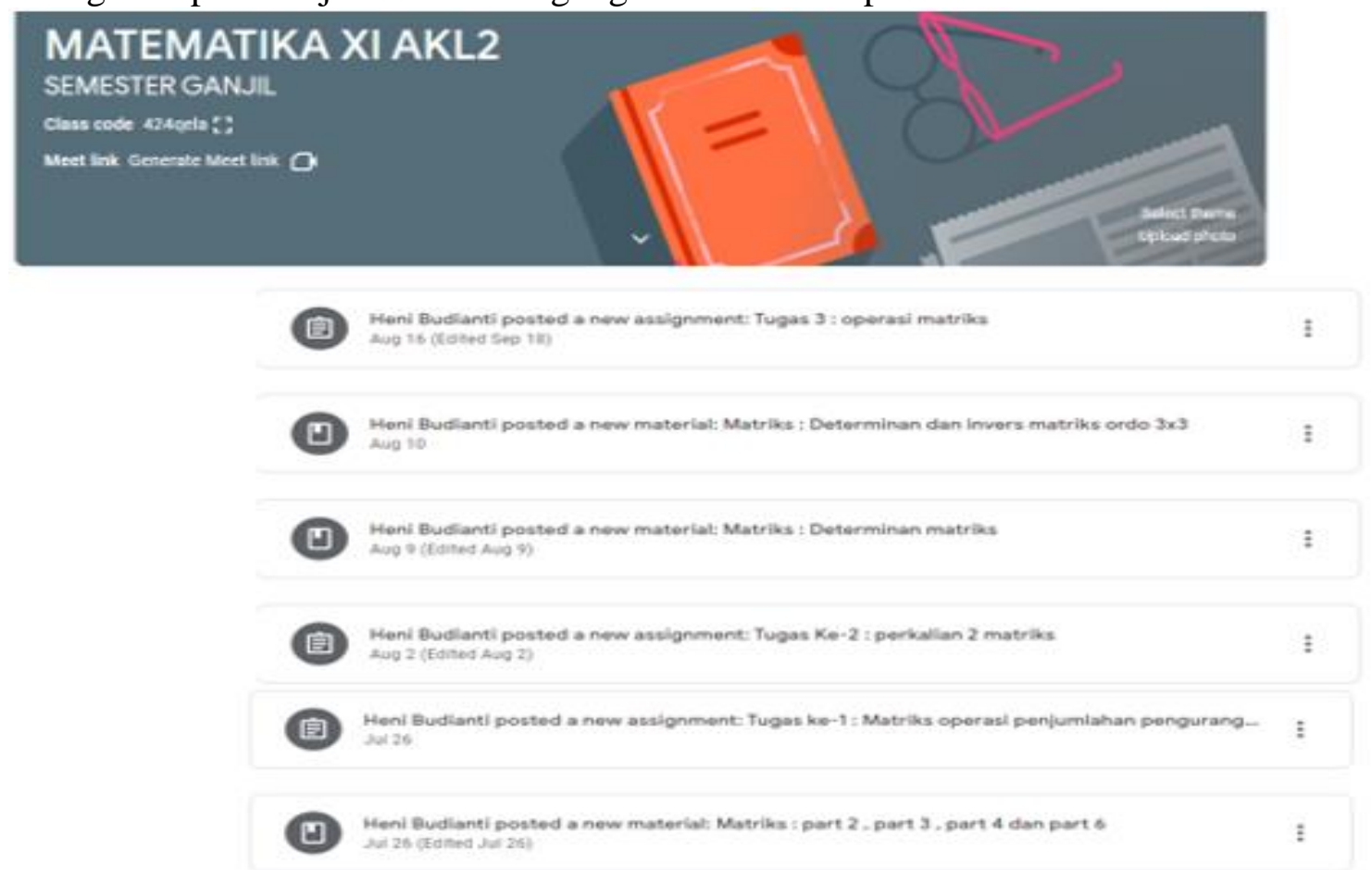

\section{Gambar 9. Tampilan google classroom guru sebagai sumber belajar siswa di pembelajaran SMART GO-ClassForMe}

3. Mengamati keaktifan siswa selama pembelajaran SMART GO-ClassForMe dan usaha siswa dalam memahami dari setiap pembelajaran, dan guru memberikan reward berupa nilai plus dari setiap bentuk keaktifan siswa baik berupa presentasi dalam menjawab setiap latihan soal, dan tugas atau keaktifan dalam memberi komentar yang membangun dalam pembelajaran. 

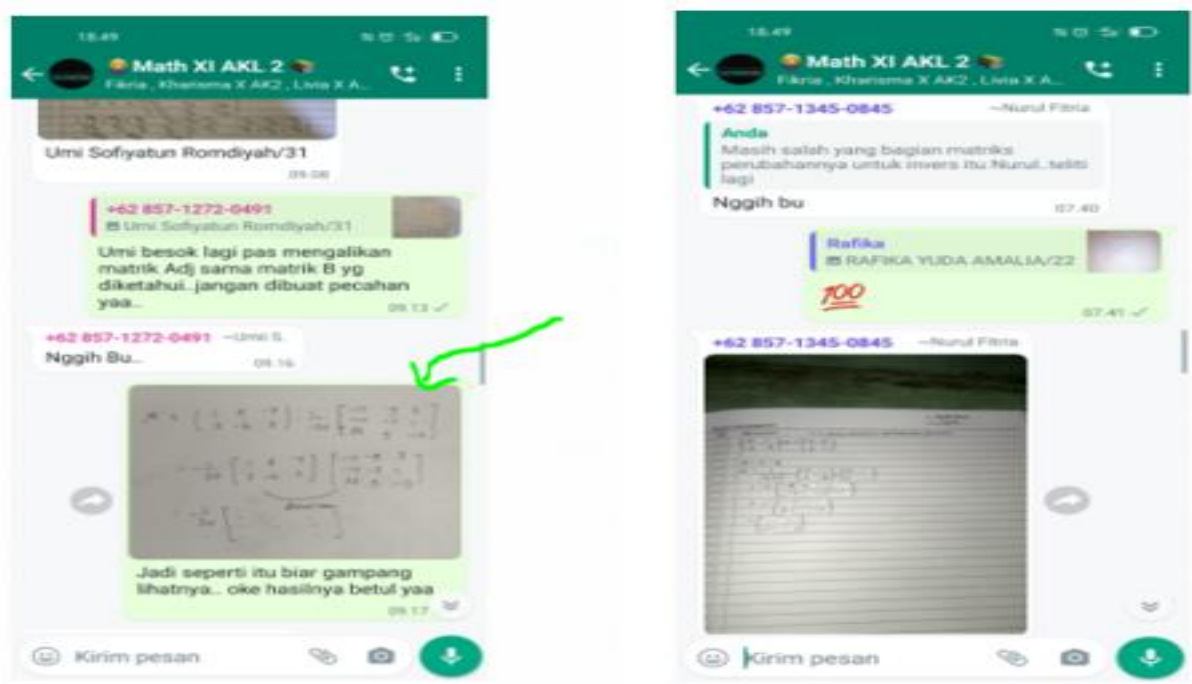

Gambar 10. Tampilan keaktifan siswa dan guru memberi arahan saat pembelajaran
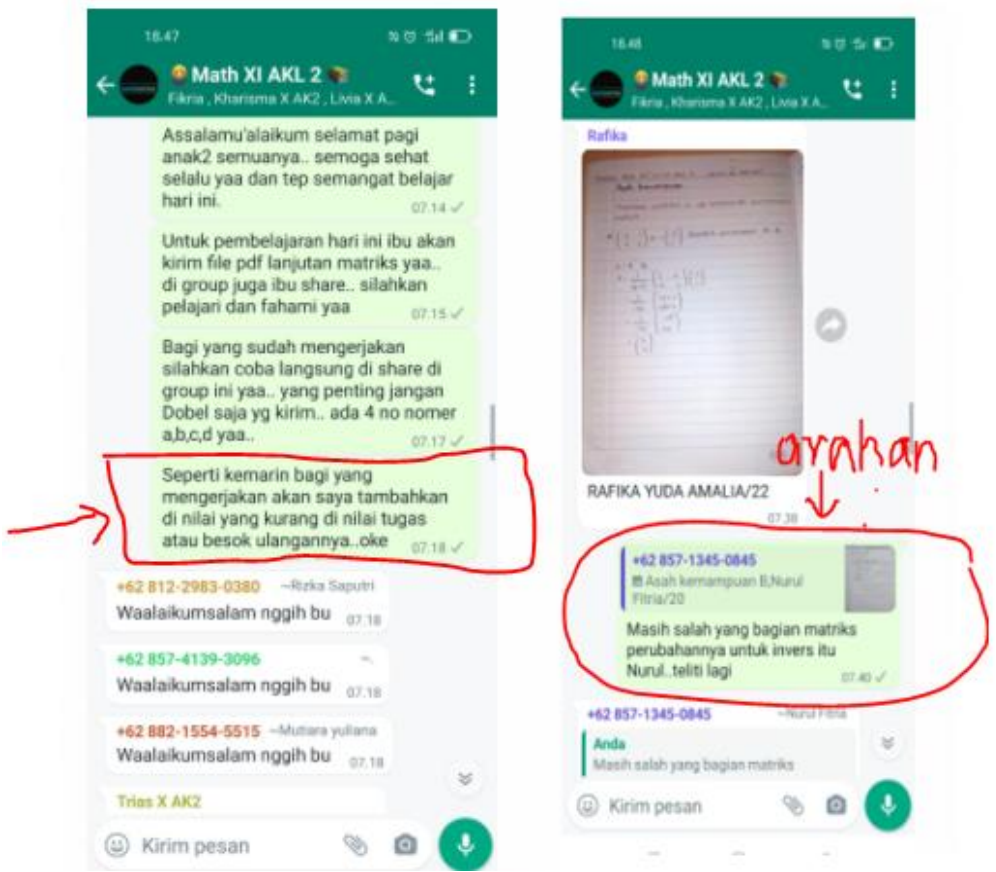

Gambar 11. Tampilan guru sebagai fasilitator saat pembahasan latihan soal di kelas pembelajaran

4. Guru sebagai elevator, setelah melakukan proses pembelajaran, guru haruslah mengevaluasi semua hasil yang telah dilakukan selama proses pembelajaran. Evaluasi ini bisa dijadikan dasar pencapaian pembelajaran. Dan bisa menambah semangat siswa untuk selalu mengerjakan tugas dengan baik. 


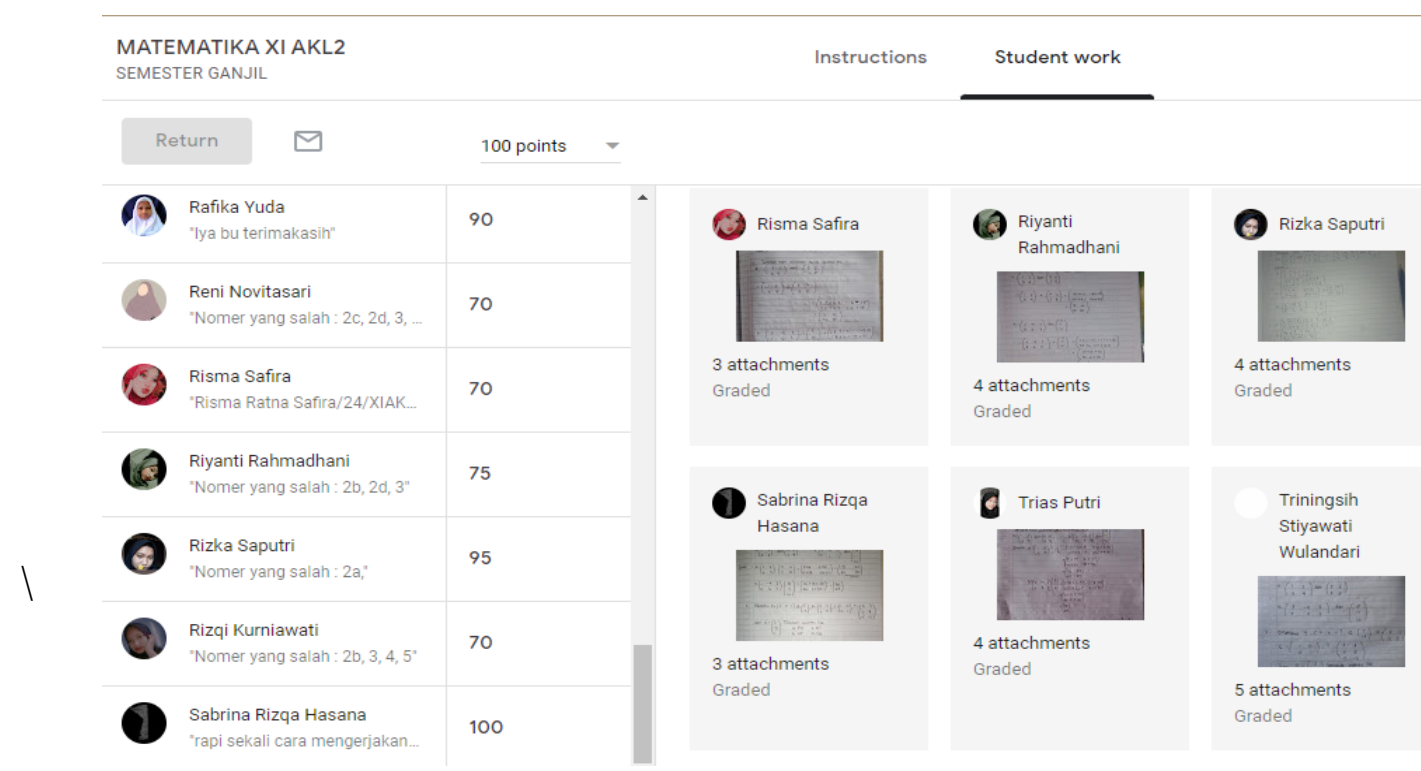

Gambar 12. Tampilan guru sebagai elevator yaitu memberi nilai tugas siswa yang di google classroom

Siswa mendapatkan informasi tautan terkait pengiriman pembelajaran SMART GOClassForMe di akun google classroom masing-masing yang telah diunggah oleh guru, sehingga siswa dapat mengakses pembelajaran SMART GO-ClassForMe dimana saja dan kapan saja. Jika siswa mengalami kesulitan dalam memahami pembelajaran, dapat membuka kembali dan mengulang pembelajaran SMART GO-ClassForMe sampai mereka memahaminya. Setelah pembelajaran,siswa diharapkan dapat menyelesaikan tugas atau ulangan harian dengan baik sehingga bahwa pembelajaran daring tidak mengurangi prestasi siswa. Tidak ada lagi tidak bisa mengikuti pelajaran dikarenakan izin atau sakit karena mereka dapat mengakses pembelajaran di lain waktu dan lebih fleksibel. Pembelajaran SMART GO-ClassForMe yang disajikan diasumsikan bahwa siswa telah mempelajari materi dengan baik dan pembelajaran dianggap selesai.

Dari tugas dan peran guru saat pembelajaran daring tersebut terpenuhi, dan guru dapat memanagement pembelajaran dengan baik, dan siswa dapat melihat alur pembelajaran yang sistematis, sehingga siswa mampu memahami cara belajar daring dengan benar dan dapat menyelesaikan tugas-tugas dengan baik. Maka diharapkan pembelajaran ini berjalan dengan baik dan hasil yang diperoleh siswa saat evalusi materi matriks juga baik dan mencapai ketuntasan pada materi Matriks.

Dengan diberlakukannya pembelajaran jarak jauh yang sudah berjalan kurang lebih 2 tahun ini menyebabkan berkurangnya semangat peserta didik dalam mengikuti pembelajaran, bahkan menjadikan mereka kurang peduli terhadap hasil belajarnya karena mereka berasumsi bahwa dalam kondisi seperti ini pasti akan selalu dimaklumi. Pola pemikiran seperti itu telah mempengaruhi tingkat antusiasmenya terhadap proses pembelajaran. Terbukti dari hasil penelitian ini yang menunjukkan tingkat partisipasi peserta didik mengikuti pelajaran dilihat dari bulan April 2021- September 2021 dan nilai rata-rata pretes dan post tes materi matriks diperoleh data sebagai berikut : 
1. Data kehadiran peserta didik

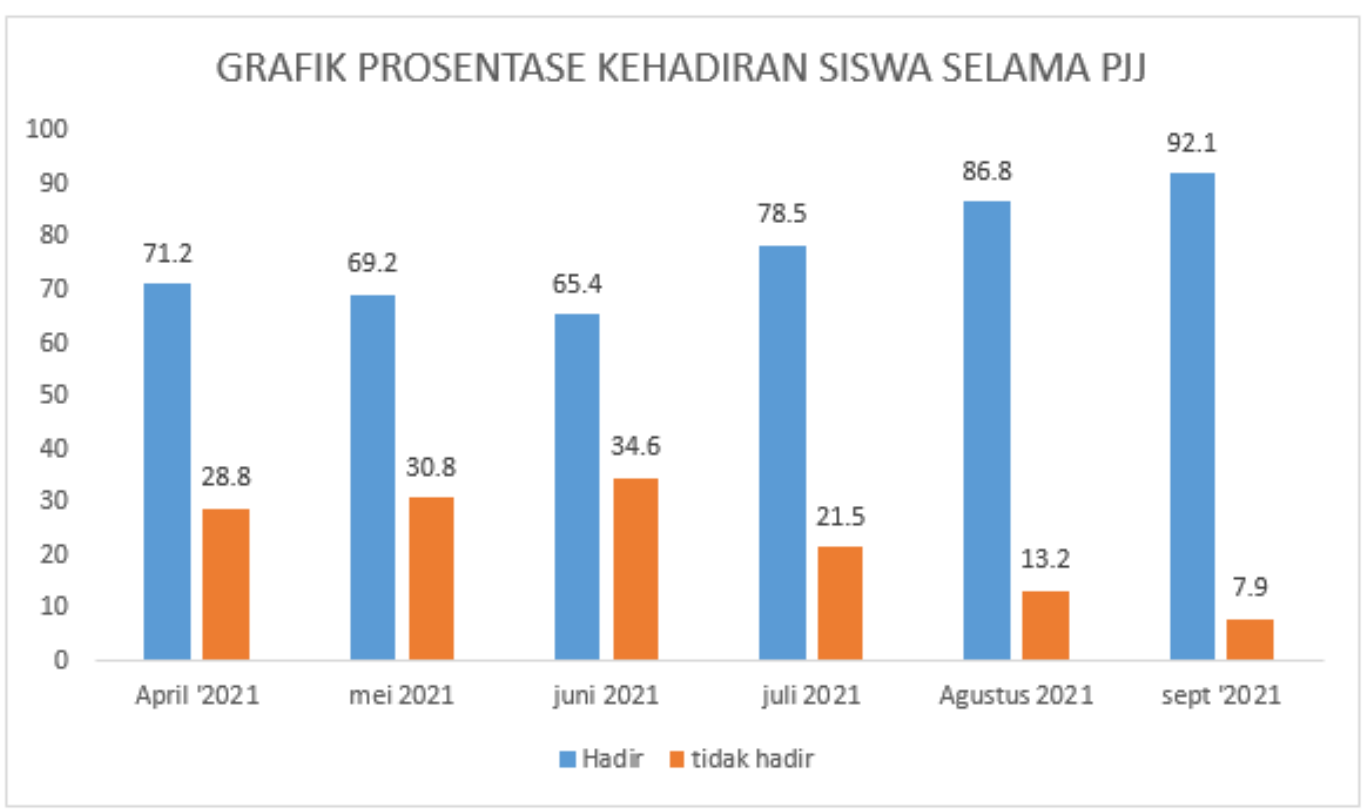

Gambar13. Grafik prosentase kehadiran di peserta didik selama PJJ

Berdasarkan grafik tersebut diketahui bahwa April 2021 sampai dengan bulan juni 2021 belum di terapkan pembelajaran SMART GO-ClassForMe terlihat bahwa tingkat ketidakhadiran peserta didik cukup tinggi. Hal ini disebabkan oleh beberapa kemngkinan, karena tingkat kebosanan dengan pembelajaran daring, kekurang pedulian peserta didik akan hasil belajar, atau metode pembelajaran daring yang monoton,dan kemungkinan karena faktor sangat tinggi angka pasien yang terkonfirmasi covid-19 sehingga diberlakukan PPKM ( Pemberlakuan Pembatasan Kegiatan Masyarakat) di bulan juni 2021 sehingga mempengaruhi tingkat kehadiran peserta didik. Bulan juli 2021 sampai dengan bulan September 2021 penulis menerapkan pembelajaran SMART GO-ClassForMe dan terlihat bahwa hasilnya peserta didik semakin disiplin dan antusias mengikuti pelajaran hal ini tercermin dalam grafik bahwa ketidakhadiran peserta didik semakin menurun.

2. Data Hasil Rata-rata Kemampuan Pemecahan Masalah materi matriks

\begin{tabular}{|c|c|c|c|}
\hline \multirow[t]{2}{*}{ No. } & \multirow[t]{2}{*}{ Statistik } & \multicolumn{2}{|c|}{ Nilai } \\
\hline & & Pretes & Posttest \\
\hline 1. & Ukuran Sampel & 35 & 35 \\
\hline 2. & Rata-rata & 49,6 & 79,03 \\
\hline 3. & Nilai Maksimum & 74 & 93 \\
\hline 4. & Nilai minimum & 20 & 60 \\
\hline
\end{tabular}

Matematika adalah ilmu tentang keteraturan, memahami konsep dan struktur bahan membuat materi lebih dipahami secara komprehensif. Jadi dengan memahami konsep dan struktur akan memudahkan transfer ilmu. Belajar matematika adalah berusaha membantu siswa membangun pengetahuan melalui proses (Sun et al., 2021; Afifah, 2012).

Penelitian ini untuk mengetahui bagaimana implementasi pembelajaran SMART GoClassForMe dapat meningkatkan hasil belajar siswa pada materi matriks di masa pandemi. Selama pelaksanaan pembelajaran daring, siswa memiliki fleksibilitas waktunya belajar. Siswa dapat belajar kapan saja dan dimanapun, tanpa dibatasi oleh ruang dan waktu. Siswa 
juga dapat berinteraksi dengan guru pada saat yang sama, seperti menggunakan panggilan video atau obrolan langsung. Pembelajaran daring dapat diberikan secara elektronik menggunakan aplikasi forum atau pesan, Pembelajaran berbasis multimedia dengan memanfaatkan teknologi dan program komputer sebagai media pembelajaran daring merupakan alternatif proses belajar membuatnya lebih menyenangkan dan mudah dipahami dan diharapkan menjadi pembelajaran yang bermakna (Sarjana, 2014a).

Pembelajaran dalam penelitian ini dengan menggunakan google classroom, google form, google meet atau pesan whatsApp. Hasil dari pembelajaran SMART GO-ClassForMe posttes kompetensi matriks dapat dinyatakan bahwa sebagian besar siswa telah melakukan pembelajaran dengan baik dan efektif seperti yang ditunjukkan oleh hasil pencapaian siswa yang meningkat atau mampu mempertahankan prestasi. Dapat diartikan bahwa dengan pembelajaran SMART GO-ClassForMe siswa merasa lebih menarik, termotivasi, tertarik, antusias dan mampu menggantikan pembelajaran tatap muka agar lebih mudah dalam memahami alur dan sistematika pembelajaran yang disampaikan khususnya dalam belajar matematika. Terlihat pada data tabel 1 yang disajikan menunjukkan hasil rata-rata kemampuan pemecahan masalah materi matriks saat pretes sebelum diberi pembelajaran SMART GO-ClassForMe sebesar 49,6 dan nilai rata-rata kemampuan pemecahan masalah materi matriks saat posttest setelah pembelajaran daring dengan SMART GO-ClassForMe. sebanyak 35 siswa adalah 79,03. Sehingga menunjukan adanya peningkatan hasil belajar selama menggunakan pembelajaran SMART GO-ClassForMe pada materi matriks pada siswa kelas XI AKL 2 SMKN 1 Juwiring di masa pandemi covid-19.

\section{KESIMPULAN}

Berdasarkan pada hasil pembahasan, maka dapat dikemukakan bahwa proses pembelajaran daring dengan menggunakan metode SMART GO-ClassForMe pada peserta didik kelas XI SMKN 1 Juwiring, mempunyai dampak yang cukup baik terutama pada pembentukan karakter siswa menjadi sadar pentingnya belajar daring secara sistematis, sehingga membuat siswa memahami cara mengikuti alur pembelajaran yang jelas.

Dengan kesadaran pembelajaran daring dengan alur yang sistematis dapat meningkatkan rasa percaya diri siswa, mampu menarik minat siswa , antusiasme siswa yang ditandai dengan meningkatnya kehadiran siswa dan meningkatnya hasil belajar siswa. Dengan hasil penelitian ini, disarankan kepada pendidik pengampu mata pelajaran matematika untuk menerapkan metode SMART GO-ClassForMe untuk meningkatkan pemahaman dan kemampuan belajar siswa selama pembelajaran jarak jauh. Sedangkan kepada kepala sekolah diharapkan mampu memberikan fasiltas serta pembinaan yang tepat agar pembelajaran jarak jauh yang dilaksanakan mampu memfasilitasi peserta didik untuk tetap semangat dalam belajar dengan hasil berpretasi yang baik.

\section{DAFTAR PUSTAKA}

Afifah, D. S. (2012). Interaksi Belajar Matematika Siswa Dalam Pembelajaran Kooperatif Tipe STAD. Jurnal Pegagogia, 1(2), 145-151.

Assidiqi, M. H. dan Woro S. 2020. Pemanfaatan Platform Digital di Masa Pandemi Covid-19. Seminar Nasional Pascasarjana 2020,Universitas NegeriSemarang.

Budhiharti, S.J dan Hardi S. 2017. Analisis Kemampuan Pemecahan Masalah Matematika Ditinjau dari Karakter Kreatif dalam Pembelajaran MEA Berbantuan Modul Scientific. Ujmer, 6(1): 38-47

Falahudin, I. 2014. Pemanfaaatan Media dalam Pembelajaran. JLW, 1(4): 104-117

Handayani, T, Hariyani N. K dan Rolisda Y. 2020. Pedampingan Belajar di Rumah Bagi Siswa Sekolah Dasar Terdampak COVID-19. Abdipraja, 1(1): 107-115

Kemdikbud. 2020. Surat Edaran Nomor 15 Tahun 2020 Tentang Pedoman Penyelenggaraan Belajar dari Rumah dalam Masa Darurat Penyebaran Corona Virus Disease (Covid19).Jakarta: Kemdikbud 
Kemdikbud. 2020. Surat Edaran Nomor 4 Tahun 2020 Tentang Pelaksanaan Kebijakan Pendidikan dalam Masa Darurat Penyebaran Corona Virus Disease (Covid-19). Jakarta:Kemdikbud

Khayati, N., \& Sarjana, S. (2015). Self-Efficacy and Creativity To Create Teacher Innovation. Jurnal Pendidikan Dan Kebudayaan, 21(3), 243-262. https://doi.org/10.24832/jpnk.v21i3.189

Murtiyasa, B. (2015). Tantangan Pembelajaran Matematika Era Global. Prosiding Seminar 17 Nasional UMS 2015. Surakarta.

Rahman .(2011). Kesalahan-kesalahan Fatal paling sering dilakukan Guru Dalam Kegiatan belajar-Mengajar. Jogjakarta. DIVA press

Sarjana, S. (2012). Pengaruh Supervisi Dan Iklim Organisasi Terhadap Kepuasan Kerja. Jurnal Kependidikan: Penelitian Inovasi Pembelajaran, 42(2), 173-186. https://doi.org/10.21831/jk.v42i2.1951

Sarjana, S. (2014a). Efforts to improve the quality of learning automotive chassis with multimedia based in class XI light vehicle engineering. Jurnal Pendidikan Dan Kebudayaan, 20(1), 30- 43. https://doi.org/10.24832/jpnk.v20i1.123

Sarjana, S., \& Khayati, N. (2016). Pengaruh Etika, Perilaku, Dan Kepribadian Guru Terhadap Integritas Guru. Jurnal Pendidikan Dan Kebudayaan, 1(3), 379-393. https://doi.org/10.24832/jpnk.v1i3.450

Setiawati, S. M. (2018). Telaah Teoritis: Apa Itu Belajar? Helper: Jurnal Bimbingan Dan Konseling FKIP UNIPA, 35(1), 31-46. https://doi.org/10.36456/helper.vol35.no1.a1458 